University of Nebraska - Lincoln

DigitalCommons@University of Nebraska - Lincoln

Faculty Publications: Department of

Entomology

Entomology, Department of

2013

\title{
Current known range of the Platte River caddisfly, Ironoquia plattensis, and genetic variability among populations from three Nebraska Rivers
}

\author{
Lindsay A. Vivian \\ U.S. Fish and Wildlife Service, lindsayviv@gmail.com \\ Michael Cavallaro \\ University of Nebraska at Kearney \\ Kate Kneeland \\ University of Nebraska-Lincoln \\ Erica Lindroth \\ University of Nebraska-Lincoln \\ W. Wyatt Hoback \\ University of Nebraska at Kearney, whoback@okstate.edu \\ See next page for additional authors \\ Follow this and additional works at: https://digitalcommons.unl.edu/entomologyfacpub \\ Part of the Entomology Commons
}

Vivian, Lindsay A.; Cavallaro, Michael; Kneeland, Kate; Lindroth, Erica; Hoback, W. Wyatt; FarnsworthHoback, Kerri M.; Harms, Robert R.; and Foster, John E., "Current known range of the Platte River caddisfly, Ironoquia plattensis, and genetic variability among populations from three Nebraska Rivers" (2013).

Faculty Publications: Department of Entomology. 343.

https://digitalcommons.unl.edu/entomologyfacpub/343

This Article is brought to you for free and open access by the Entomology, Department of at DigitalCommons@University of Nebraska - Lincoln. It has been accepted for inclusion in Faculty Publications: Department of Entomology by an authorized administrator of DigitalCommons@University of Nebraska - Lincoln. 
Authors

Lindsay A. Vivian, Michael Cavallaro, Kate Kneeland, Erica Lindroth, W. Wyatt Hoback, Kerri M. FarnsworthHoback, Robert R. Harms, and John E. Foster 


\title{
Current known range of the Platte River caddisfly, Ironoquia plattensis, and genetic variability among populations from three Nebraska Rivers
}

\author{
Lindsay A. Vivian - Michael Cavallaro $\cdot$ Kate Kneeland • \\ Erica Lindroth · W. Wyatt Hoback - Kerri M. Farnsworth-Hoback • \\ Robert R. Harms $\cdot$ John E. Foster
}

Received: 21 August 2012/ Accepted: 3 May 2013

(C) Springer Science+Business Media Dordrecht 2013

This article is a U.S. government work, and is not subject to copyright in the United States.

\begin{abstract}
The Platte River caddisfly (Ironoquia plattensis Alexander and Whiles 2000) was recently described from a warm-water slough along the Platte River in central Nebraska and was considered abundant at the type locality. Surveys of 48 sites in 1999 and 2004 found eight additional sites with this species on the Platte River. The caddisfly was not found at the type locality in 2004 and one additional site in 2007, presumably because of drought conditions. Because of its apparent rarity and decline, the Platte River caddisfly is a Tier I species in Nebraska. For this project, surveys for the caddisfly were conducted at 113 new and original sites primarily along the Platte, Loup, and Elkhorn Rivers between 2009 and 2011. These surveys identified 30 new sites with the caddisfly. Larval densities were quantified at a subset of inhabited sites, and there was a large variation of densities observed. Seven sites on other Nebraska drainages were found to support morphologically similar caddisflies, presumably the Platte River caddisfly. Because of the discovery of populations outside the Platte River drainage, amplified fragment length polymorphism (AFLP) was used to determine the amount of genetic variability and breeding among sites on the Platte, Loup, and Elkhorn Rivers. Analysis of
\end{abstract}

L. A. Vivian $(\bowtie) \cdot$ R. R. Harms

United States Fish and Wildlife Service, Grand Island,

NE 68801, USA

e-mail: lindsayviv@gmail.com

M. Cavallaro · W. Wyatt Hoback ( $\square)$.

K. M. Farnsworth-Hoback

Biology Department, University of Nebraska at Kearney,

Kearney, NE 68849, USA

e-mail: hobackww@unk.edu

K. Kneeland · E. Lindroth · J. E. Foster

Department of Entomology, University of Nebraska-Lincoln,

Lincoln, NE 68583, USA molecular variance (AMOVA) suggested moderate gene flow among the three river systems and that there was more genetic variation within populations than between populations. Differentiation, but not total divergence, was exhibited by the northernmost population from the Elkhorn River. Because it may be considered an indicator species and is vulnerable to ongoing habitat loss and degradation, all Platte River caddisfly populations should be conserved.

Keywords Aestivation - Intermittent hydroperiod · Slough $\cdot$ Trichoptera $\cdot$ AFLP

\section{Introduction}

The Platte River caddisfly (I. plattensis Alexander and Whiles) was formally described in 2000 from an intermittent, warm-water slough in central Nebraska on Mormon Island just south of the City of Grand Island (Fig. 1). This site is herein referred to as the type locality. This area is owned and maintained by The Crane Trust (previously The Platte River Whooping Crane Maintenance Trust) and has not been topographically altered for agriculture like the majority of the Platte River Valley (Sidle et al. 1989; Whiles et al. 1999; Alexander and Whiles 2000). Like other members of Ironoquia, the Platte River caddisfly emigrates from the water to aestivate in the surrounding terrestrial environment for about four months during the summer (Flint 1958; Williams and Williams 1975; Wiggins 1977; Alexander and Whiles 2000). This dormant stage likely represents an adaptation to withstand summer dry periods in intermittent wetlands (Williams 1996).

During a life history study in 1997-1998, the Platte River caddisfly was found to be abundant at the type locality and represented $57 \%$ of aquatic insect emergence 


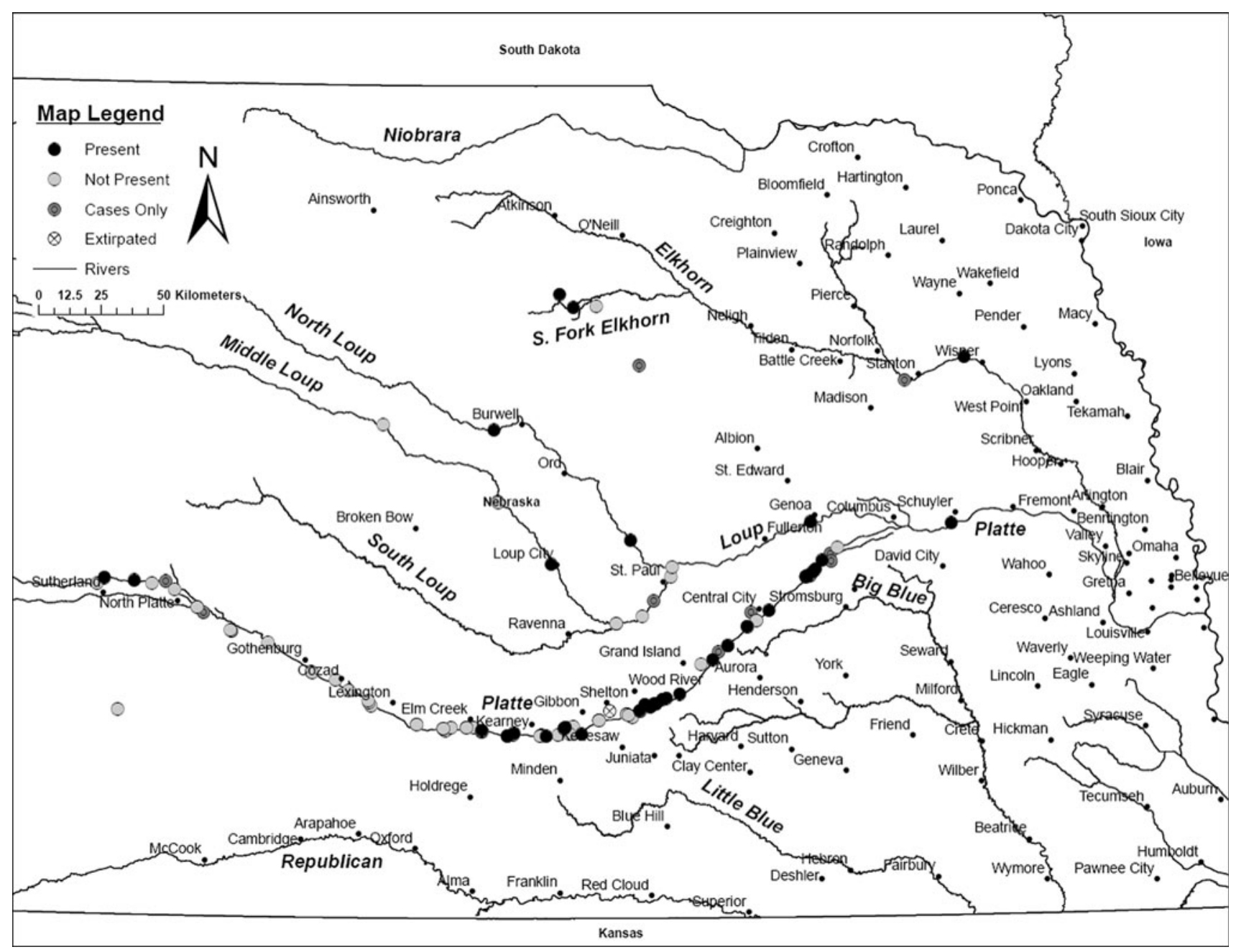

Fig. 1 Map depicts 2009-2011 survey efforts conducted in search of sites with the Platte River caddisfly, I. plattensis, along the Platte, Loup, and Elkhorn River in Nebraska

production from the slough (Whiles and Goldowitz 2001). In 1997-1998, Whiles et al. (1999) reported that an average of $805 \pm 194( \pm 1 \mathrm{SD})$ larvae $/ \mathrm{m}^{2}$ was present in the aquatic environment, while 219 larvae $/ \mathrm{m}^{2}$ were estimated to emigrate from the slough; thereby representing an important transfer of biomass from the aquatic to terrestrial environment.

Shortly after it was described, additional surveys for the Platte River caddisfly were conducted in areas with potentially suitable habitat in 1999 and 2004 (Goldowitz 2004). An intensive survey of 48 locations identified eight additional sites with the caddisfly on the Platte River along a $100 \mathrm{~km}$ stretch between Gibbon and Central City, Nebraska. Of the 48 surveys, 10 occurred on the Loup River, and these surveys were negative (Goldowitz 2004).

Monitoring efforts in 2004 and 2007 did not detect the Platte River caddisfly at two of the nine sites identified by Goldowitz, including the type locality, despite 7 years of consistent emergence patterns there and presumably because of persistent drought conditions (Goldowitz 2004; Riens and Hoback 2008). Because of its apparent limited distribution and propensity towards local extinctions, the Platte River caddisfly is listed as a Tier 1 species (those at risk of extinction across their range) in Nebraska (Schneider et al. 2005). The species was also considered for federal protection under the Endangered Species Act in 2012 [U.S. Fish and Wildlife Service (USFWS) 2012].

While conducting surveys in 2009 , we identified sites that supported populations of morphologically similar caddisflies on the Loup and Elkhorn Rivers. Sites with the caddisfly on all three drainages appeared similar in hydroperiod and vegetation composition. Meanwhile, it has been noted that morphologically comparable populations that are reproductively isolated can represent cryptic species (Martin and Bermingham 2000; Parsons and Shaw 2001). Therefore, we wanted to investigate whether or not the caddisflies from the Loup and Elkhorn Rivers were a different, undescribed species or subspecies of Ironoquia. 
There are sites between the Platte, Loup, and Elkhorn Rivers that are a minimum of $50 \mathrm{~km}$ apart, and the absence of suitable habitat between isolated sites could potentially represent a barrier to dispersal and subsequent breeding for species with poor dispersal abilities (Myers et al. 2001; Blakely et al. 2006). The absence of suitable habitat between river systems is likely a product of geographic isolation; whereas within the Platte drainage, isolation is likely more a product of habitat degradation (Vivian pers. obs.). Based on our observations, the Platte River caddisfly appears to be a weak flier, and genetic techniques can provide insight into a species' dispersal ability in the absence of directly observing significant dispersal events (Clobert et al. 2001; Kelly et al. 2002; Blakely et al. 2006). Amplified fragment length polymorphism (AFLP) has been used to determine the amount of gene flow within a species (Kelly et al. 2002; Clark et al. 2007; Kneeland 2011). Therefore, it is appropriate that AFLP be used to test the hypothesis that there is breeding among extant Platte River caddisfly populations. The objectives of this project were to: (1) conduct additional surveys for the Platte River caddisfly in Nebraska, (2) quantify aquatic larval densities at a subset of sites to establish a baseline dataset, (3) determine the amount of genetic variability among populations tested and their degree of relatedness, and (4) determine if there is gene flow among the three river systems.

\section{Methods}

\section{Study area}

Surveys for the Platte River caddisfly were conducted along the Platte, Loup, and Elkhorn River drainages in Nebraska (Fig. 1). The Platte River is formed at the confluence of the South Platte and North Platte Rivers east of the City of North Platte, Nebraska. Platte River water levels are tied to snowmelt from Colorado and Wyoming and local precipitation events (Eschner et al. 1981). The Loup and Elkhorn Rivers are tributaries of the Platte, thereby comprising part of the Platte Basin; they drain portions of the Nebraska Sandhills, and their flows are more dependent on input from the Ogallala Aquifer than precipitation events (Peterson et al. 2008). Elevations range from $980 \mathrm{~m}$ above sea level at the western sites of the study area to $580 \mathrm{~m}$ above sea level at the eastern locations.

Each river surveyed for the Platte River caddisfly contained adjacent side channels (sloughs) from past meanderings that either had a direct surface connection to the main river channel or were separated from the main channel by natural berms. These sloughs had little or no flow and a presence of organic sediment that had accumulated as a result of being cut off from the flow of the main channel. For this study, sloughs were characterized as lentic bodies of water with stands of emergent vegetation and typical wetland flora, including cattails (Typha spp.), willows (Salix spp.), and duckweed (Lemna spp.). These sloughs are subject to fluctuations in the groundwater table and surface water inputs (Wesche et al. 1994) and typically have an intermittent hydroperiod (Whiles et al. 1999), holding water about $75-90 \%$ of the time (Goldowitz 2004).

\section{Identification of new populations}

Google Earth $^{\circledR}$ (Google, Inc., Mountain View, CA) satellite imagery was used to locate potential Platte River caddisfly habitat. Potential habitat was considered to be any side channel or linear depression near the main river channel with signs of emergent aquatic vegetation and presence of water. After identification of potential habitat, we obtained landowner information to gain access to private land. Surveys were also conducted at wildlife management areas (WMAs) managed by the Nebraska Game and Parks Commission, rights-of-way along roadsides, and land owned by non-governmental organizations (NGOs) including: the Nebraska Public Power District (NPPD), Central Nebraska Public Power and Irrigation District (CNPPID), Headwaters Corporation, The Nature Conservancy (TNC), and The Crane Trust.

Terrestrial sampling-For the purposes of this study, a site was defined as a slough that was potentially suitable to the Platte River caddisfly with at least $100 \mathrm{~m}$ of terrestrial habitat between it and another such area. Searches for terrestrial larvae were conducted for $30 \mathrm{~min}$, and if no Platte River caddisfly larvae were found, the site was considered to be unoccupied. Cases with larvae were distinguished from old, discarded cases by the presence of the head capsule, visible at the open end of the larval case.

Between 2009 and 2011, 93 sites along the Platte River (including the North Platte River), 13 sites on the Loup River (including the Middle Loup and North Loup Rivers), five sites along the Elkhorn River (including the South Fork of the Elkhorn), one site along the Cedar River, and one site along Wallace Creek were sampled for the Platte River caddisfly (Fig. 1). These numbers do not include the site described in Geluso et al. (2011). A Garmin ${ }^{\circledR}$ (Olathe, KS) GPSMAP ${ }^{\circledR} 60 \mathrm{CSx}$ was used to record the coordinates of each location sampled.

Aquatic sampling-Aquatic sampling was conducted in mid-May 2009 and mid-May 2010 at five of the nine original sites identified by Goldowitz and 12 new sites to quantify larval densities. In 2010, five sites were sampled twice in an attempt to capture caddisfly emigration from the slough. In each slough and for each sampling effort, 
four $1 \mathrm{~m}$ passes within the top three $\mathrm{cm}$ of substrate were made using a $30 \mathrm{~cm}$, D-frame net, and then corrected by a factor of 3.33 to obtain number of larvae $/ \mathrm{m}^{2}$. Four passes were made at all sloughs sampled except at Site "I" in 2009. On the Loup and Elkhorn Rivers, only presence/ absence data were collected.

\section{AFLP analysis}

Caddisfly larvae were collected from three sites on the Platte River and one site each on the Loup and Elkhorn Rivers using a metal sieve (25 cm diameter) (Fig. 2). Adults were also collected from these sites using a standard sweep net and a 75-watt mercury vapor light trap (Fig. 2). Twenty individuals from each site were preserved for genetic analysis by placing them directly into $95 \%$ ethanol following collection. Samples were stored at $-80{ }^{\circ} \mathrm{C}$ upon reaching the laboratory. Thirty stable flies, Stomoxys calcitrans (Diptera: Muscidae), were used as the out-group. $S$. calcitrans is an appropriate outgroup, because it is another insect species and completely unrelated to the caddisfly.

DNA extraction-All samples were washed in $70 \%$ ethanol and rinsed with nanopure ${ }^{\circledR}$ (Thermo Scientific, Waltham, MA) water prior to DNA extraction. DNA was extracted from the thorax of each individual following a modified cetyl trimethylammonium bromide (CTAB) method (Doyle and Doyle 1987). Extracted DNA samples were suspended in $1 \times$ TE $(10 \mathrm{mM}$ Tris-HCL; $0.1 \mathrm{mM}$ EDTA) buffer, and a NanoDrop ${ }^{\circledR}$ spectrophotometer (Nanodrop 2000, Thermo Scientific, Wilmington, DE) was used to determine the quality and quantity of the DNA, after which samples were stored at $-20^{\circ} \mathrm{C}$. Prior to initiating the AFLP procedure, DNA was diluted to 20-100 ng/ $\mu$ l.

Amplified fragment length polymorphism-For the AFLP procedure, we followed a protocol modified from Vos et al. (1995) and optimized by Kneeland (2011). DNA was cleaved using common (EcoRI) and rare (MseI) site restriction enzymes. Oligonucleotide adapters were ligated onto the sticky ends of the restriction fragments, and the resulting fragments were amplified non-selectively using primers that matched the sequences of the adapters. The DNA was selectively amplified using primers with a three base-pair (bp) extension sequence in addition to the adapter sequence (Table 1). The resulting AFLP product was run on a $6.5 \%$ polyacrylamide gel and visualized on a GeneReadIR infrared laser scanner (LI-COR Biosciences, Lincoln, NE).

Data scoring and analysis-Gels were calibrated using an IRD-700 labeled 50-700 bp sizing standard and scored using the software program SAGA MX 3.2 (LI-COR Biosciences, Lincoln, NE). The data were converted to a Boolean vector for further analysis, with a "1" indicating band presence and a " 0 " indicating absence. A bootstrapping analysis was conducted to obtain the coefficient of variation for all data using "Bootsie", which is based on an established algorithm (Tivang et al. 1994) and is publicly available.

Popgene 1.32 (Yeh and Boyle 1997) was used to assess genetic diversity at the population level with assumed Hardy-Weinberg equilibrium. The percentage of polymorphic loci and Nei's gene diversity were calculated for each location. Popgene was also used to estimate $\mathrm{G}_{\mathrm{ST}}$, which measures the amount of genetic variation within
Fig. 2 Map of sampling locations of populations represented in the study

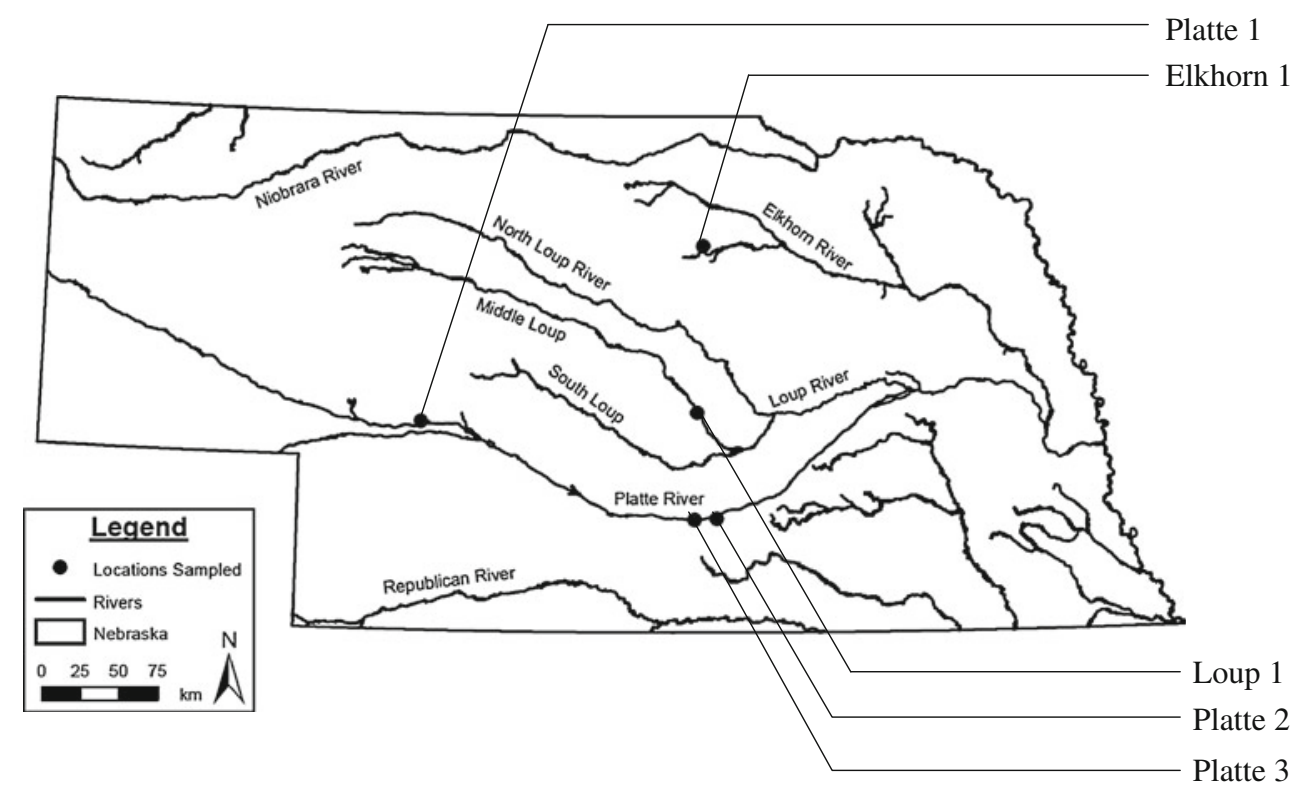


Table 1 Primers and adapters used in selective amplification

\begin{tabular}{lll}
\hline Oligonucleotide & Purpose & Sequence $\left(5^{\prime}-3^{\prime}\right)$ \\
\hline EcoRI-forward adapter & Adapter ligation & CTCGTAGACTGCGTACC \\
EcoRI-reverse adapter & Adapter ligation & AATTGGTACGCAGTCTAC \\
$M s e$-forward adapter & Adapter ligation & GACGATGAGTCCTGAG \\
$M s e$-reverse adapter & Adapter ligation & TACTCAGGACTCAT \\
EcoRI primer & Pre-amplification & GACTGCGTACCAATTC \\
Ms I primer & Pre-amplification & GATGAGTCCTGAGTAA \\
M-CTG & Selective amplification & GACTGCGTACCAATTC+CTG* \\
M-CAC & Selective amplification & GATGAGTCCTGAGTAA+CAC* \\
E-ACT & Selective amplification & GACTGCGTACCAATTC+ACT* \\
\hline
\end{tabular}

Primers with three basepair extension sequence in addition to the adapter sequence are indicated with $(*)$

populations and within the total population among locations sampled (Nei 1973).

Arlequin v. 3.5 (Excoffier et al. 2005) was used to conduct the analysis of molecular variance (AMOVA) and to calculate $\mathrm{F}_{\mathrm{ST}}$, where $\mathrm{F}=$ the inbreeding coefficient, $\mathrm{S}=$ subpopulations, and $\mathrm{T}=$ the total population (Wright 1950). The AMOVA tested for genetic structure between and within populations. Significance was tested by running 1,023 permutations of the data.

\section{Results}

Identification of new populations

\section{Terrestrial sampling}

Along the Platte River, 23 new sites that supported the Platte River caddisfly were identified out of 93 sites sampled, and at least five sites documented by Goldowitz (2004) (not all were sampled) still support a caddisfly population (Fig. 2). During surveys, 12 sites were identified that contained caddisfly cases only and no live individuals, and 54 sites were unoccupied (Fig. 2). Out of 18 sites surveyed on the Loup and Elkhorn Rivers, seven sites with a caddisfly population were identified, two sites contained cases only, and ten sites contained neither cases nor caddisflies (Fig. 2). No terrestrial larvae were observed at one historic site near Shelton, Nebraska, and the caddisfly is presumed to be extirpated from this location (Fig. 1). One site with cases only was found along the Cedar River, and no caddisflies were found at Wallace Creek.

\section{Aquatic sampling}

During 2009 and 2010 aquatic sampling, the highest mean larval density observed was $125.7 \pm 95.47 / \mathrm{m}^{2}$ at Site "N". Eleven of the 17 sites on the Platte River sampled were
Table 2 Mean number ( \pm 1 S.E.) of Platte River caddisfly larvae collected through aquatic sampling along the Platte River

\begin{tabular}{llcl}
\hline Site & Larvae $/ \mathrm{m}^{2} 2009$ & Larvae $/ \mathrm{m}^{2} 2010$ & Larvae $/ \mathrm{m}^{2} 2010-2012$ \\
\hline $\mathrm{A}$ & $0.83 \pm 0.83$ & $0.83 \pm 0.83$ & - \\
$\mathrm{B}$ & - & $1.7 \pm 1.67$ & - \\
$\mathrm{C}$ & $1.7 \pm 0.96$ & $0 \pm 0$ & - \\
$\mathrm{D}$ & - & $1.7 \pm 0.97$ & - \\
$\mathrm{E}$ & $54.0 \pm 14.14$ & $45.8 \pm 8.95$ & $98.2 \pm 43.53$ \\
$\mathrm{~F}$ & - & $0.83 \pm 0.83$ & - \\
$\mathrm{G}$ & - & $0 \pm 0$ & - \\
$\mathrm{H}$ & - & $5.8 \pm 2.91$ & - \\
$\mathrm{I}$ & $23.2 \pm 4.98$ & $29.1 \pm 10.65$ & $15.0 \pm 2.15$ \\
$\mathrm{~J}$ & - & $12.5 \pm 4.78$ & - \\
$\mathrm{K}$ & $4.2 \pm 3.15$ & $75.8 \pm 47.55$ & $43.3 \pm 22.21$ \\
$\mathrm{~L}$ & - & $7.5 \pm 6.43$ & $0 \pm 0$ \\
$\mathrm{M}$ & - & $1.7 \pm 0.96$ & - \\
$\mathrm{N}$ & - & $125.7 \pm 95.47$ & - \\
O & - & $30.8 \pm 22.02$ & - \\
P* & - & $0 \pm 0$ & - \\
Q & - & $10.0 \pm 5.61$ & $0.83 \pm 0.83$ \\
\hline
\end{tabular}

Sites with one asterisk $(*)$ denote sites where live individuals have been observed, but where no larvae were detected during aquatic sampling

found to have densities of less than 10 individuals $/ \mathrm{m}^{2}$ (Table 2).

\section{Genetic analysis}

Site restriction enzymes produced 218 informative markers. The AMOVA results showed most of the variation to be within populations $(62.15 \%)$ (Table 3). A bootstrap analysis of the data demonstrated that the AFLP analysis accounted for over $95 \%$ of the genetic variation within each population. Statistical analysis of the data revealed moderately high gene flow $(\mathrm{Nm}=1.2728)$ among the caddisfly populations (Larson et al.1984) as an $\mathrm{Nm}$ value 
Table 3 Two-level AMOVA fixation indices and results

\begin{tabular}{llclc}
\hline Source of variation & D. F. & Sum of squares & Variance components & Percentage of variation \\
\hline Among groups & 2 & 570.073 & $5.03503 \mathrm{~V}_{\mathrm{a}}$ & 17.83 \\
Among populations within groups & 2 & 252.201 & $5.6567 \mathrm{~V}_{\mathrm{b}}$ & 20.03 \\
Within populations & 92 & $1,614.871$ & $17.55294 \mathrm{~V}_{\mathrm{c}}$ & 62.15 \\
Total & 96 & $2,437.144$ & 28.24468 & $0.057 \pm 0.0070$ \\
Fixation indices & $\mathrm{V}_{\mathrm{c}}$ and $\mathrm{F}_{\mathrm{st}}$ & 0.37854 & $P$ value & \multirow{2}{*}{} \\
\hline
\end{tabular}

Significance tests were accomplished with 1,023 permutations

Fig. 3 UPGMA dendrogram (Nei 1972) with genetic distances of Platte River caddisfly (I. plattensis) populations and outgroup

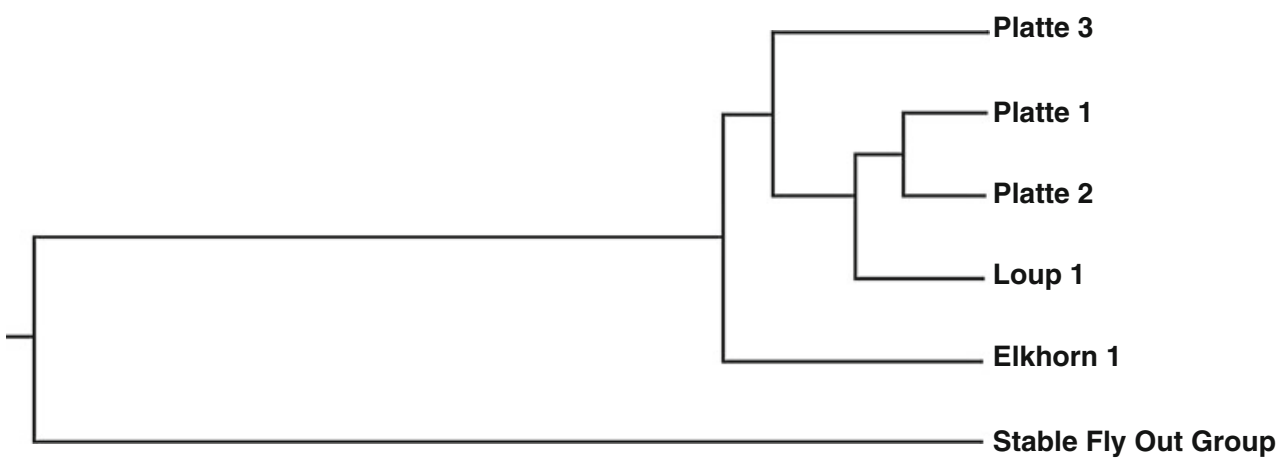

Table 4 Genetic identity (above diagonal) and genetic distance (below diagonal) (Nei 1978; Kelly et al. 2002) of Platte River caddisfly populations and stable fly outgroup

\begin{tabular}{lllllll}
\hline Population name & Platte 3 & Elkhorn 1 & Platte 1 & Platte 2 & Loup 1 & Stable fly outgroup \\
\hline Platte 3 & - & 0.9152 & 0.9347 & 0.9273 & 0.9118 & 0.7301 \\
Elkhorn 1 & 0.0886 & - & 0.9263 & 0.9138 & 0.897 & 0.6796 \\
Platte 1 & 0.0675 & 0.0766 & - & 0.9663 & 0.9528 & 0.6863 \\
Platte 2 & 0.0755 & 0.0902 & 0.0343 & - & 0.9583 & 0.6863 \\
Loup 1 & 0.0923 & 0.1087 & 0.0483 & 0.0426 & - & 0.7068 \\
Stable fly outgroup & 0.3146 & 0.3863 & 0.3835 & 0.3765 & 0.3471 & - \\
\hline
\end{tabular}

$>1.0$ infers high gene flow (Clark et al. 2007). $\mathrm{Nm}$ is the unit assigned to denote the amount of gene flow between populations and is derived from the result of the sampled population number $(\mathrm{N})$ and rate of migration among those populations (m) (Larson et al. 1984; McDermott and McDonald 1993; Clark et al. 2007). This can be estimated from $\mathrm{F}_{\mathrm{ST}}\left[\mathrm{F}_{\mathrm{ST}} \sim 1 /(4 \times \mathrm{Nm}+1)\right]$ (Allendorf and Luikart 2007).

$\mathrm{F}_{\mathrm{ST}}$ was 0.37854 and $\mathrm{G}_{\mathrm{ST}}$ was 0.2820 , and both values are considered low $(<0.5)$ (Clark et al. 2007). These values indicate that the majority of the genetic variation is within populations rather than between populations (Clark et al. 2007).

A dendrogram was created to display genetic distances among the populations tested using the UPGMA method modified from the Neighbor-joining method (Fig. 3) (Sneath and Sokal 1973; Clark et al. 2007). Genetic distance measures the amount of gene substitutions per locus and is an indication of differentiation (Nei 1972). The dendrogram results indicate that the "Elkhorn 1" population is the most differentiated and is of the earliest origin among all populations tested. "Elkhorn1" shared 89-92\% of common bases, whereas the remaining caddisfly populations sampled shared 91-96\% (Table 4).

\section{Discussion}

With the identification of 23 new caddisfly populations on the Platte River between 2009 and 2011, the known range of the Platte River caddisfly is now approximately five times larger east to west than the range previously reported for the species (Goldowitz 2004). Surveys also identified seven Platte River caddisfly populations on the Loup and 
Elkhorn River systems in Nebraska, which expands the known range of the species north to south.

Although the identification of new caddisfly populations has led to an increase in the known range of this species, the distribution of the Platte River caddisfly is disjunct. Currently, a $155 \mathrm{~km}$ gap in sites with the Platte River caddisfly occurs between Elm Creek, Nebraska and Hershey, Nebraska (near North Platte) along the Platte River. Within this gap, 24 surveys for the caddisfly were conducted, but only two sites were found with cases only, and no live individuals were observed. The absence of the caddisfly within this area of the Platte River could be a result of habitat loss and/or degradation. Low numbers of the caddisfly may also remain undetected by our sampling methodology or be impacted by the time of year that the surveys were conducted.

Within the $155 \mathrm{~km}$ gap, several canals divert water for irrigation, and this water diversion has resulted in the loss of several wetlands along the Platte River (Currier et al. 1985; Sidle et al. 1989). Six mainstem dams along the Platte River upstream of the gap have also resulted in wetland losses along the river corridor (Currier et al. 1985; Sidle et al. 1989). During this study, several depressions at Dogwood WMA were observed, and these areas were dry but showed signs of previous beaver, Castor canadensis, activity, indicating that changes in water levels had occurred. Meanwhile, the Platte River in this area is incised because of a diversion return, and this may have resulted in the loss of sloughs as channel incision is known to lead to adjacent wetland deterioration and losses (Fischenich and Morrow 2000).

The methodology used to detect new Platte River caddisfly populations in 2009-2011 was to search the ground surface for aestivating larvae. However, in May 2010, aestivating larvae were observed buried in the ground about five to ten $\mathrm{cm}$ below the ground surface. This was previously an undocumented behavior in Trichoptera and was first observed at Wild Rose Slough on property owned by The Crane Trust (Geluso et al. 2011). This behavior may be a means to avoid desiccation (Wiggins et al. 1980). This behavior has subsequently been observed at two additional locations. The burial behavior was largely discovered, in part, because no aestivating larvae were observed aboveground in 2010 at the Wild Rose Slough (Geluso et al. 2011), which may be result of a lack of shading at this slough, and soil temperatures around this slough can reach $54{ }^{\circ} \mathrm{C}\left(130^{\circ} \mathrm{F}\right)$ in the summer (Vivian pers. obs. 2010). At forested sites, larvae are more readily observed aboveground.

Following the discovery of the burial behavior, we used a shovel at seven sites in 2010 in a non-standard fashion to augment our terrestrial sampling effort. However, the number of larvae observed using a shovel was not counted, as these data were not a part of our standard sampling. Two sites with cases only were found using a shovel, but no sites were identified with an extant population only through digging. Future terrestrial surveys should include the use of a shovel, although occupied sites to date have always had larvae and pupae above ground.

\section{Aquatic sampling}

Aquatic sampling in 2009 and 2010 was used as a means to document Platte River caddisfly larval densities. These data could be used for subsequent sampling efforts in the future to capture population trends for the species. Geluso et al. (2011) and Whiles et al. (1999) also report on methods to quantify Platte River caddisfly larval densities. Our data are not directly comparable to these reported values, because Geluso et al. (2011) sampled earlier in May than this study, and Whiles et al. (1999) sampled a different volume of sediment (Meyer et al. 2011) and at different time periods.

From this study, a large range in larval densities among sites on the Platte River was observed, demonstrating that the Platte River caddisfly is more abundant in some locations than others. For instance, from this study, Sites "E" and "N" were found to support the largest caddisfly populations. Geluso et al. (2011) and Whiles et al. (1999) reported larval densities more than $70 \%$ greater than what was observed at Site "N", while eight other sites sampled as a part of this study, were found to have densities of less than two individuals $/ \mathrm{m}^{2}$. A related species, I. punctatissima, has been observed with similar population characteristics (Gray and Johnson 1988).

The gradient of larval densities observed may be explained by macro and microhabitat differences, such as variations in hydroperiod, vegetation types, substrate, etc. Both sites sampled by Geluso et al. (2011) and Whiles et al. (1999) support wet meadow habitat surrounded by grassland vegetation, whereas most other sites sampled support woody vegetation. Both Crane Trust sites also have similar, intermittent hydroperiods, and permanent waters may limit caddisfly population levels at some locations. For instance, sites with water depth greater than one meter and with permanent hydroperiods had fewer larvae, such as at Site "L". Permanent waters may be more favorable to fish and amphibians that can prey on caddisfly larvae (Wissinger et al. 2003; Whiles and Goldowitz 2005; Tarr and Babbit 2007; Vivian and Cavallaro pers. obs. 2011).

Sites with relatively low larval densities could indicate that some populations may be recovering from a previous decline in numbers or that some sites with the caddisfly represent marginal habitat. For instance, the caddisfly was not detected at the type locality in 2004 (Goldowitz 2004) and was not observed at the site again until 2010 (Geluso 
et al. 2011). This was likely a result of persistent drought conditions in the 2000s (Goldowitz 2004; Riens and Hoback 2008). Despite surveys in 2009 and 2010, the caddisfly has not been observed at the site near Shelton since 2007.

One factor affecting habitat quality and larval densities could be the lack of emergent vegetation at some sites, which would reduce the amount of autochthonous material in the slough. In other wetlands and streams, shredders, like the caddisfly, are generally absent from areas without sufficient autochthonous or allochthonous material (Vannote et al. 1980). Our observations suggest that the amount of organic matter is important in determining the number of larvae at a site (USFWS 2011).

Differences in substrate may also affect habitat quality. Studies have shown that substrate type can be an important factor in influencing macroinvertebrate assemblages (Downes et al. 2000; Evans and Norris 1997; Braccia and Voshell 2006). The Platte River caddisfly appears to have an association with coarse substrate material. A targeted survey effort at Site "L" found that the caddisfly occurred at greater densities in areas with sand and coarse substrate material that had accumulated behind interspersed beaver dams as opposed to the silt deposits encountered throughout most of the slough (Cavallaro pers. obs. 2011). Similar observations have been recorded at two other sites (Vivian pers. obs. 2009).

One other concern regarding surveys was the discovery of 12 sites with only cases and no larvae or adults. Laboratory data suggest that Platte River caddisfly cases degrade slowly as has been observed with other species (McCabe and Gotelli 2003), and we recommend that cases not be used to established caddisfly presence (Vivian 2010). Sites with only cases may represent recent extirpation events or populations with very low larval densities.

\section{Genetic analysis}

Using AFLP enables comparisons for assessing genetic diversity among closely related species and populations (Mueller and Wolfenbarger 1999; Kelly et al. 2002). Our surveys demonstrate that the Platte River caddisfly is not limited to the Platte River as was previously thought. However, some populations are isolated from one another by distances of up to $50 \mathrm{~km}$ or more. This isolation may either be a product of geographic isolation, such as what exists between river drainages, or habitat degradation and loss, such as what has occurred along the western reaches of the Platte River in Nebraska. Gene flow among caddisfly populations appears to be relatively high. However, even species with larger $\mathrm{Nm}$ values may contain populations that are completely isolated from the remaining populations (Larson et al. 1984). This seems to be the case with the
Elkhorn 1 site, which was the most divergent from the other populations tested and is the site that is the most distant from the others sampled. The four remaining populations were more closely related, indicating that any isolation along the Platte River is relatively recent, whereas the Elkhorn site has likely been separated from the other populations for a longer time period.

Here we also report a low $\mathrm{F}_{\mathrm{ST}}$ value and low $\mathrm{G}_{\mathrm{ST}}$ value for the populations tested and that most of the genetic variation is within populations (Kelly et al. 2002; Clark et al. 2007; Krumm et al. 2008). The $\mathrm{F}_{\mathrm{ST}}$ value we report here is similar to what has been observed in Wormaldia tagananana, which is endemic to the Canary Islands and has a low dispersal ability, and similar to other values observed in caddisflies with wide distributions (Kelly et al. 2002). This indicates that there is still substantial genetic variation within the Platte River caddisfly populations tested (Kelly et al. 2002).

According to Williams (1996), aquatic insects that occur in temporary freshwaters most likely disperse as adults as opposed to larval drift. It has also been reported that Limnephildae are strong fliers (Svensson 1974; Kelly et al. 2002) with body size and wing length corresponding to dispersal ability (Kovats et al. 1996). Platte River caddisfly adults are small compared to many other Nearctic limnephilid species (Alexander and Whiles 2000). Based on observations of Platte River caddisfly adults, this species appears to be a poor flier. Platte River caddisfly adults are also active for a short time period of about 3 weeks (Whiles et al. 1999), and this could limit its dispersal ability compared to other caddisflies with longer adult lifespans (Svensson 1972). Despite these observations, the caddisfly occupies more than one river drainage, and interpopulation breeding is occurring. However, poor flight capabilities could limit the ability of the caddisfly to recolonize suitable habitat following disturbance eventssuch as may be the case with the extirpated site near Shelton-especially when coupled with ongoing and future habitat loss and degradation. This could leave remaining populations vulnerable to extirpation as a result of stochastic events.

\section{Conclusion}

Reynolds (2003) identifies vulnerable populations as those with either a small/declining range size or low/declining abundances. Our results demonstrate that the Platte River caddisfly has a larger range than was initially known for the species, although this is likely the result of increased sampling rather than range expansion. Further monitoring of its distribution will be necessary to determine whether changes in range size are occurring. Monitoring changes to 
its habitat will also be important in the conservation of this species.

The Platte River caddisfly could be considered an important indicator of a healthy watershed. For instance, the caddisfly is absent from the most degraded, incised, and dewatered stretch of the Platte River. Meanwhile, Platte River channel degradation is ongoing, and the trend is moving eastward (Murphy et al. 2004). Unless this trend is slowed, such as through ongoing conservation and management efforts, additional Platte River caddisfly populations may become extirpated in the future resulting in the isolation of remaining populations. While the Loup and Elkhorn River systems are less developed, these drainages are also vulnerable to ongoing and future habitat modification because of increasing grain prices and water usage.

Other efforts to conserve caddisfly populations and manage its habitat could be informed by future habitat studies. For instance, Colburn and Garretson Clapp (2006) completed a habitat model for Phanocelia canadensis, a bog-dwelling caddisfly, by measuring several water quality parameters and performing a principal components analysis (PCA). It was found that low $\mathrm{pH}$, presence of nutrients, and surface area best predicted the occurrence of $P$. canadensis (Colburn and Garretson Clapp 2006). Conducting a PCA with habitat data collected from several sites with and without the Platte River caddisfly could lead to a better understanding of why the caddisfly occurs in greater densities at some sites than others. The differentiation between the Elkhorn population and the other caddisfly populations suggests that the conservation of all populations is important to preserve genetic variation in the species. Further genetic analyses of additional sites could help identify whether or not the caddisfly is vulnerable to habitat fragmentation and isolation of sites (Tscharntke et al. 2002).

The Platte River caddisfly may have experienced historic declines across its range, and human alterations that affect wetlands, such as diversion projects or impoundments, could continue to adversely impact the species. Efforts to restore or improve flows in the Platte River, as is being done under the Platte River Recovery and Implementation Program, could benefit the caddisfly; however, care should be taken to not create permanent waters that would allow colonization by fish, which may act as predators on the caddisfly (Vivian 2010).

Acknowledgments We would especially like to thank: Dr. Mary Harner of The Crane Trust for her guidance on the project and recommendations to improve the manuscript; Dr. Keith Geluso of UNK for helpful discussions on the caddisfly; Mike Fritz of NGPC for valuable input on this project; Dr. Keith Koupal of NGPC and University of Nebraska at Kearney for reviewing this manuscript; Dr. Steve Skoda of the USDA-ARS for technical assistance and helpful comments regarding the results; and Dr. Justin Payne for assistance in analyzing our genetic results. Funding for this project was provided by: the United States Fish and Wildlife Service (USFWS), a Nebraska Game and Parks Commission (NGPC) State Wildlife Grant, the Nebraska Public Power District (NPPD), the Central Nebraska Public Power and Irrigation District (CNPPID), the Central Platte Natural Resources District (CPNRD), and the UNK Student Research Services Council.

We would like to give a special thanks to the following people for field assistance and project guidance: Michelle McPherron, Stephanie Butler, Jess Lammers, David Schumann, and Garrett Dow, Dave Baasch (Headwaters Corporation), Tim Tunnell (Headwaters Corporation), Nanette Whitten (TNC), Chris Helzer (TNC), Jim Jenniges (NPPD), Mark Czaplewski (CPNRD), Mark Peyton (CNPPID), Ben Wheeler (NGPC), Jeff Runge (USFWS), Beth Goldowitz, and Frank Vivian. We also appreciate all the private landowners, NGPC, the Headwaters Program, Crane Trust, and TNC for allowing access to their lands for this work.

\section{References}

Alexander KD, Whiles MR (2000) A new species of Ironoquia (Trichoptera: Limnephilidae) from an intermittent slough of the Central Nebraska Platte River, Nebraska. Entomol News 111(1):1-7

Allendorf FW, Luikart G (2007) Conservation and the genetics of populations. Blackwell Publishing, Malden

Blakely TJ, Harding JS, McIntosh AR, Winterbourn MJ (2006) Barriers to the recovery of aquatic insect communities in urban streams. Freshw Biol 51:1634-1645

Braccia A, Voshell JR Jr (2006) Environmental factors accounting for benthic macroinvertebrate assemblage structure at the sample scale in streams subjected to a gradient of cattle grazing. Hydrobiologia 573(1):55-73

Clark PL, Molina-Ochoa J, Martinelli S, Skoda SR, Isenhour DJ, Lee DJ, Krumm JT, Foster JE (2007) Population variation of the fall armyworm, Spodoptera frugiperda, in the Western Hemisphere. J Insect Sci 7(5):10

Clobert J, Danchin E, Dhont AA, Nichols JD (eds) (2001) Dispersal. Oxford University Press, Oxford

Colburn EA, Garretson Clapp FM (2006) Habitat and life history of a northern caddisfly, Phanocelia canadensis (Trichoptera: Limnephilidae), at the southern extreme of its range. North Nat 13(4):537-550

Currier PJ, Lingle JR, VanDerwalker JG (1985) Migratory bird habitat on the Platte and north Platte Rivers in Nebraska. The Platte River Whooping Crane Critical Habitat Maintenance Trust, Wood River

Downes BJ, Lake PS, Schreiber ESG, Glaister A (2000) Habitat structure, resources and diversity: the separate effects of surface roughness and macroalgae on stream invertebrates. Oecologia 123(4):569-581

Doyle JJ, Doyle JL (1987) A rapid DNA isolation procedure for small quantities of fresh leaf tissue. Phytochem Bull 19:11-15

Eschner T, Hadley R, Crowley K (1981) Hydrologic and morphologic changes in the Platte River Basin: a historical perspective. Open File Report. U.S. Geological Survey, Denver, pp 811125

Evans LJ, Norris RH (1997) Prediction of benthic macroinvertebrate composition using microhabitat characteristics derived from stereo photography. Freshw Biol 37:621-633

Excoffier L, Laval G, Schneider S (2005) Arlequin ver. 3.0: an integrated software package for population genetics data analysis. Evol Bioinform Online 1:47-50 
Fischenich C, Morrow JV Jr (2000) Reconnection of floodplains with incised channels. Technical note EMRRP SR-09, $11 \mathrm{pp}$

Flint OS (1958) The larva and terrestrial pupa of Ironoquia parvula (Trichoptera, Limnephilidae). J NY Entomol Soc 66(1/2):59-62

Geluso K, Harner MJ, Vivian LA (2011) Subterranean behavior and other notes for Ironoquia plattensis (Trichoptera: Limnephilidae) in Nebraska. Ann Entomol Soc Am 104(5):1021-1025

Goldowitz BG (2004) Survey for the Platte River caddisfly (Ironoquia plattensis) in Nebraska. Final Report, Nebraska Game and Parks Commission. Lincoln, NE. 16 pp

Gray L, Johnson KW (1988) Trophic structure of benthic macroinvertebrates in Kings Creek. Trans Natl Acad Sci 91(3/ 4): $178-184$

Kelly LC, Rundle SD, Bilton DT (2002) Genetic population structure and dispersal in Atlantic Island caddisflies. Freshw Biol 47:1642-1650

Kneeland KM (2011) Genetic variability of the stable fly, Stomoxys calcitrans (L.) (Diptera: Muscidae) assessed on a global scale using amplified fragment length polymorphism. Ph.D. Dissertation. University of Nebraska, Lincoln, Nebraska

Kovats ZE, Ciborowski JJH, Corkum LD (1996) Inland dispersal of adult aquatic insects. Freshw Biol 36:265-276

Krumm JT, Hunt TE, Skoda SR, Hein GL, Lee DJ, Clark PL, Foster JE (2008) Genetic variability of the European corn borer, Ostrinia nubilalis, suggests gene flow between populations in the Midwestern United States. J Insect Sci 8:72

Larson A, Wake DB, Yanev KP (1984) Measuring gene flow among populations having high levels of genetic fragmentation. Genetics 106:293-308

Martin AP, Bermingham E (2000) Regional endemism and cryptic species revealed by molecular and morphological analysis of a widespread species of Neotropical catfish. Proc R Soc Lond 267:1135-1141

McCabe DJ, Gotelli NJ (2003) Caddisfly diapause aggregations facilitate benthic invertebrate colonization. J Anim Ecol 72(6):1015-1026

McDermott JM, McDonald BA (1993) Gene flow in plant pathosystems. Annu Rev Phytopathol 31:353-373

Meyer CK, Peterson SD, Whiles MR (2011) Quantitative assessment of yield, precision, and cost-effectiveness of three wetland invertebrate sampling techniques. Wetlands 31:101-112

Mueller UG, Wolfenbarger LL (1999) AFLP genotyping and fingerprinting. Trends Ecol Evol 14(10):389-394

Murphy PJ, Randle TR, Fotherby LM, Daraio LA (2004) The Platte River channel: history and restoration. Technical Report. U.S. Department of the Interior, Technical Service Center, Denver, Colorado, $177 \mathrm{pp}$

Myers MJ, Sperling FAH, Resh VH (2001) Dispersal of two species of Trichoptera from desert springs: conservation implications for isolated vs connected populations. J Insect Conserv 5:207-215

Nei M (1972) Genetic distance between populations. Am Nat 106(949): 283

Nei M (1973) Analysis of gene diversity in subdivided populations. Proc Natl Acad Sci 70:3321-3323

Nei M (1978) Estimation of average heterozygosity and genetic distance from a small number of individuals. Genetics 89(3): $583-590$

Parsons YM, Shaw KL (2001) Species boundaries and genetic diversity among Hawaiian crickets of the genus Laupala identified using amplified fragment length polymorphism. Mol Ecol 10(7):1765-1772

Peterson SM, Stanton JS, Saunders AT, Bradley JR (2008) Simulation of ground-water flow and effects of ground-water irrigation on base flow in the Elkhorn and Loup River Basins, Nebraska. Publications of the US Geological Survey. Scientific Investigations Report 2008-5143
Reynolds JD (2003) Life histories and extinction risk. In: Blackburn TM, Gaston KJ (eds) Macroecology. Blackwell, Oxford, pp 195-217

Riens J, Hoback WW (2008) Population status and potential threats to the Platte River caddisfly (Ironoquia plattensis). Conference proceedings of the North Central Branch of the Entomological Society of America, Columbus, $\mathrm{OH}$

Schneider R, Humpert M, Stoner K, Steinauer G (2005) The Nebraska natural legacy project: a comprehensive wildlife conservation strategy. The Nebraska Game and Parks Commission, Lincoln

Sidle JG, Miller ED, Currier PJ (1989) Changing habitats in the Platte River Valley of Nebraska. Prair Nat 21(2):91-104

Sneath PHA, Sokal RR (1973) Numerical taxonomy. W. H. Freeman, San Francisco

Svensson BW (1972) Flight periods, ovarian maturation, and mating in Trichoptera at a south Swedish stream. Oikos 23(3):370-383

Svensson BW (1974) Population movements of adult Trichoptera at a south Swedish stream. Oikos 25(2):157-175

Tarr M, Babbit K (2007) The importance of hydroperiod in wetland assessment. University of New Hampshire Cooperative Extension, Durham

Tivang JG, Nienhuis J, Smith OS (1994) Estimation of sampling variance of molecular marker data using the bootstrap procedure. Theor Appl Genet 89:259-264

Tscharntke T, Steffan-Dewenter I, Kruess A, Thies C (2002) Characteristics of insect populations on habitat fragments: a mini review. Ecol Res 17:229-239

USFWS (2011) Platte River Caddisfly (Ironoquia plattensis) Surveys and Habitat Monitoring Final Report. Unpublished report. U.S. Fish and Wildlife Service. Nebraska Field Office, Grand Island, Nebraska, $82 \mathrm{pp}$

USFWS (2012) Endangered and threatened wildlife and plants: 12-month finding on a petition to list the Platte River caddisfly as endangered or threatened. Fed Regist 77(169):52650 52673

Vannote RL, Minshall GW, Cummins KW, Sedell JR, Cushing CE (1980) The river continuum concept. Can J Fish Aquat Sci 37:130-137

Vivian LA (2010) Updates on the distribution and population status of the Platte River caddisfly, Ironoquia plattensis, and an assessment of threats to its survival. Thesis, University of Nebraska at Kearney

Vos P, Hogers R, Bleeker M, Reijans M, van de Lee T, Hornes M, Frijters A, Pot J, Peleman J, Kuiper M, Zabeau M (1995) AFLP: a new technique for DNA fingerprinting. Nucleic Acids Res 23(21):4407-4414

Wesche TA, Skinner QD, and Henszey RJ (1994) Platte River wetland hydrology study. Final Report. U.S. Bureau of Reclamation and Wyoming Cooperative Fish and Wildlife Research Unit, $165 \mathrm{pp}$

Whiles MR, Goldowitz BS, Charlton RE (1999) Life history and production of a semi-terrestrial limnephilid caddisfly in an intermittent Platte River wetland. J N Am Benthol Soc 18(4):533-544

Whiles MR, Goldowitz BS (2001) Hydrologic influences on insect emergence production from central Platte River wetlands. Ecol Soc Am 11(6):1829-1842

Whiles MR, Goldowitz BS (2005) Macroinvertebrate communities in central Platte River wetlands: patterns across a hydrological gradient. Wetlands 25(2):462-472

Wiggins GB (1977) Larvae of the North American caddisfly genera (Trichoptera). University of Toronto Press, Toronto and Buffalo

Wiggins GB, Mackay RJ, Smith IM (1980) Evolutionary and ecological strategies of animals in annual temporary pools. Arch Hydrobiol 58:97-206 
Williams DD (1996) Environmental constraints in temporary fresh waters and their consequences for the insect fauna. J N Am Benthol Soc 15(4):634-650

Williams DD, Williams NE (1975) A contribution to the biology of Ironoquia punctatissima (Trichoptera: Limnephilidae). Can Entomol 107:829-832

Wissinger SA, Brown WS, Jannot JE (2003) Caddisfly life histories along permanence gradients in high-altitude wetlands in Colorado (USA). Freshwater Biol 48:255-270
Wright S (1950) Genetical structure of populations. Nature 166:247-249

Yeh FC, Boyle TJB (1997) Population genetic analysis of codominant and dominant markers and quantitative traits. Belg $\mathrm{J}$ Bot 129:157 